\title{
PENERAPAN MODEL PEMBELAJARAN KOOPERATIF TIPE NUMBER HEAD TOGETHER UNTUK MENINGKATKAN AKTIVITAS DAN HASIL BELAJAR PADA MATA PELAJARAN IPS TERPADU DENGAN KOMPETENSI DASAR MENDESKRIPSIKAN HUBUNGAN ANTARA KELANGKAAN SUMBER DAYA DENGAN KEBUTUHAN MANUSIA YANG TIDAK TERBATAS KELAS VIII-C SMP NEGERI 1 JANGKAR SEMESTER GENAP TAHUN PELAJARAN 2015/2016
}

\author{
Ahmad Hafas Rasyidi \\ Nawawi Agus Jaya
}

\begin{abstract}
Abstrak: Penelitian ini dilaksanakan sejak tanggal 20 April sampai dengan 30 Mei 2015 dengan obyek penelitian siswa kelas VIII-C sebanyak 28 siswa. Desain penelitian ini adalah model skema Hopkins, dengan mengguanakan 4 fase, yaitu perencanaan, tindakan, observasi dan refleksi. Untuk memperoleh data dalam penelitian ini menggunakan teknik observasi, wawancara dan tes. Analisis data penelitian ini menggunakan analisa deskriptif kualitatif. Hasil yang diperoleh dalam penelitian ini menunjukkan adanya peningkatan aktivitas belajar dan hasil belajar siswa. Aktivitas belajar siswa dalam proses pembelajaran sebelum tindakan memenuhi kriteria cukup aktif. Dari hasil analisis aktivitas siklus I diperoleh persentase 78,57\% dan ulangan harian pada siklus I diperoleh ketuntasan klasikal 78,57\% Hal ini menunjukkan bahwa penerapan pembelajaran menggunakan model pembelajaran dengan pembelajaran Numbered Head Together (NHT) pada siklus I belum berhasil maka dilanjutkan pada siklus II. Hasil pembelajaran siklus II, aktivitas belajar siswa berada dalam kategori aktif dengan persentase $86.11 \%$, sedangkan analisis ulangan harian pada siklus II diperoleh ketuntasan klasikal sebesar $85,71 \%$. Keberhasilan siswa pada ulangan harian menunjukkan bahwa penerapan model pembelajaran Numbered Head Together (NHT) telah berhasil meningkatkan hasil belajar siswa. Maka dapat disimpulkan bahwa model pembelajaran yang digunakan oleh guru sangat mempengaruhi aktivitas dan hasil belajar siswa. Hal ini terbukti dalam penerapan model pembelajaran Numbered Head Together (NHT) pada mata pelajaran IPS Terpadu siswa kelas VIII-C SMP Negeri 1 Jangkar Kabupaten Situbondo tahun pelajaran 2015/2016 yang telah mencapai ketuntasan secara klasikal.
\end{abstract}

Kata Kunci : $\quad$ Model Pembelajaran Numbered Head Together, Aktivitas Belajar, Hasil Belajar

\begin{abstract}
The research was conducted from April $20^{\text {th }}$ until May $30^{\text {th }} 2015$ with the research object was students of Class VIII-C as many as 28 students. The design of this study is a Hopkins scheme model, with 4 phases, that wew planning, action, observation and reflection. Data collection technique which used in this study were observation, interviews and tests. Data analysis in this study used a qualitative descriptive analysis. The results of this study showed an increase in student's learning activity and student's learning outcomes. Student's learning activities before the action was quite active criteria. From the analysis of student's learning activity on the first cycle obtained $78.57 \%$ and the percentage of daily tests on the first cycle obtained classical mastery $78.57 \%$. This shows that the
\end{abstract}


implementation of Numbered Head Together (NHT) learning model in the first cycle was not successful, and then this study would be continued to the second cycle. Student's learning activity in the second cycle was in the active category with the percentage of $86.11 \%$, while the analysis of daily tests on the second cycle obtained classical mastery $85.71 \%$. The achievement of students on daily tests showed that Numbered Head Together (NHT) learning model have been successful and have been able to bring students to increase their learning outcomes. It can be concluded that the learning models which used by teachers greatly affect to student's learning activity learning outcomes. It can be proven in the implementation of Numbered Head Together (NHT) learning model in Integrated Social Science Subject on Class VIII-C State Junior High School 1 Jangkar Situbondo, which has achieved the classical mastery.

Keywords : Numbered Head Together (NHT) Learning Model, Student's Learning Activity and Learning Outcomes.

\section{PENDAHULUAN}

Model pembelajaran dipengaruhi oleh beberapa faktor antara lain, tujuan, bahan, kemampuan guru dan kondisi siswa. Sebagai pendidik, guru harus menguasai model yang akan diterapkan dan tidak terpaku pada satu model pembelajaran. Model penbelajaran yang digunakan guru harus membangun suasana interaksi belajar yang dapat menumbuhkan minat belajar, semangat belajar dan mempertinggi perolehan hasil belajar.

Adapun strategi pembelajaran yang dimaksud Vygotsky adalah metode pembelajaran kooperatif. Menurut Davidson dan Kroll (dalam Lei, 2005:151), belajar kooperatif adalah kegiatan yang berlangsung dalam lingkungan belajar, sehingga siswa dalam kelompok kecil saling berbagi ide-ide dan bekerja secara kolaboratif untuk menyelesaikan tugas akademik.

\begin{tabular}{|c|}
\hline $\begin{array}{l}\text { Menurut } \begin{array}{c}\text { Nurhadi } \\
\text { pelaksanaan }\end{array} \text { strategi pembelajaran } \\
\text { pelaperatif salah satunya dapat dilakukan } \\
\text { kooperan model Numbered Head Together } \\
\text { dengan suatu } \\
\text { (NHT). NHT ini merupakan suatu } \\
\text { pendekatan yang telah dikembangkan oleh } \\
\text { Spencer Kagen (2003) untuk melibatkan } \\
\text { banyak siswa dalam menelaah materi yang } \\
\text { tercakup dalam suatu pelajaran dan } \\
\text { mengecek pemahaman mereka terhadap isi } \\
\text { pelajaran tersebut. }\end{array}$ \\
\hline
\end{tabular}

Melihat permasalahan tersebut di atas, maka peneliti tertarik untuk mengadakan penelitian tindakan kelas dengan judul "Penerapan Pembelajaran Kooperatif Model Numbered Head Together Untuk Meningkatkan Aktivitas dan Hasil Belajar pada Mata Pelajaran IPS Terpadu dengan Kompetensi Dasar Mendeskripsikan Hubungan Antara Kelangkaan Sumberdaya dengan Kebutuhan Manusia yang Tidak Terbatas Kelas VIII-C SMP Negeri I Jangkar Semester Genap Tahun Pelajaran 2015/2016".

\section{METODE PENELITIAN}

Pendekatan yang digunakan dalam penelitian ini adalah pendekatan kualitatif. Adapun ciri-ciri pendekatan kualitatif menurut Sugiyono (2005:20), yaitu (1) menggunakan lingkungan alamiah sebagai sumber data langsung; (2) bersifat deskriptif analistik; (3) lebih menekankan proses daripada hasil; (4) analisa data bersifat induktif, karena penelitian tidak dimulai dari deduksi teori tetapi dari lapangan yakni fakta empiris; (5) mengutamakan makna. Ciri tersebut diperkuat oleh pendapat Moelong (dalam Fahmi, 2006:27) bahwa fenomena penelitian ini juga sesuai dengan karakteristik penelitian kualitatif, yaitu (1) menggunakan latar alamiah seperti apa adanya di lapangan; (2) penelitian sebagai instrumen utama, maksudnya disamping pengumpul data dan menganalisis data, 
peneliti terlibat langsung dalam prows penelitian; (3) hasil penelitian bersifat deskriptif; (4) desain bersifat sementara; dan (5) batas permasalahan ditentukan fokus penelitian.

Jenis penelitian tindakan ini termasuk penelitian tindakan kelas. Rancangan pembelajaran yang digunakan didasarkan dari model Hopkins, yaitu penelitian tindakan kelas yang digambarkan dalam bentuk spiral yang terdiri dari empat fase
(PGSM, 1995:8), yaitu fase perencanaan (planning); tindakan (action); pengamatan (observation); dan refleksi (reflection). Penelitian ini berorientasi pada pengkajian masalah-masalah praktis yang dihadapi guru dalam kelas, dan hasilnya dapat diaplikasikan oleh guru sendiri dalam rangka memperbaiki pelaksanaan pembelajaran. Adapun rancangan penelitian Hopkins tersebut adalah sebagai berikut.

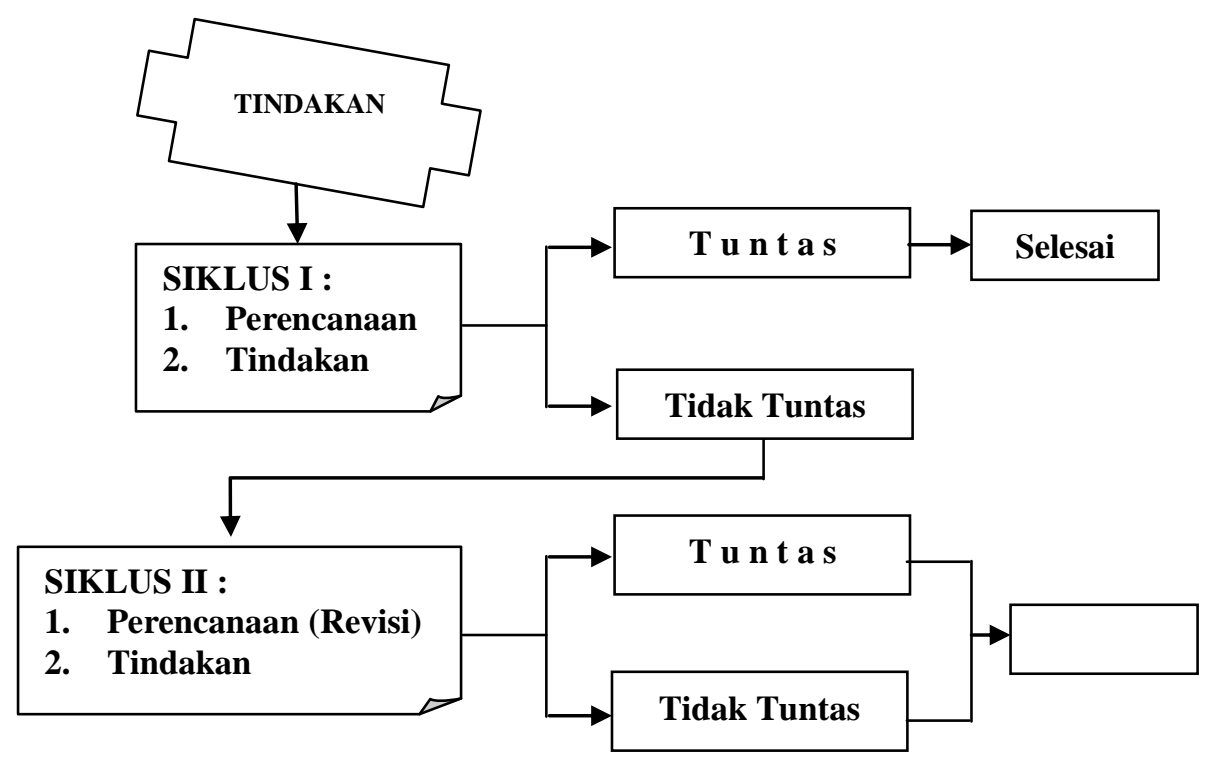

Gambar 1. Skema Hopkins

Penelitian ini direncanakan menggunakan satu siklus dengan rincian tiga kali pertemuan melalui penerapan model pembelajaran $N H T$. Jika pada pertemuan satu sampai dengan tiga, hasil belajar siswa sudah mencapai ketuntasan, maka pelaksanaan siklus dihentikan. Namun jika belum mencapai ketuntasan, maka penelitian ini akan dilanjutkan pada siklus berikutnya.

\section{Subjek Penelitian}

Subjek dalam penelitian ini adalah siswa kelas VIII-C SMP Negeri 1 Jangkar Kabupaten Situbondo semester genap tahun pelajaran 2015/2016 dengan jumlah 28 siswa. Dimana jumlah siswa laki-laki yaitu 15 orang dan jumlah perempuan 13 orang. Kelas VIII-C merupakan kelas yang heterogen hal ini terlihat dari beragamnya tingkat sosial ekonomi siswa dan jugs tingkat kemampuan siswa dalam mengikuti kegiatan pembelajaran.

\section{Teknik Pengumpulan Data}

Teknik pengumpulan data adalah caracara yang digunakan untuk mengumpulkan data. Ada beberapa cara yang dapat digunakan untuk mengumpulkan data yang secara garis besar dapat dibedakan menjadi empat yaitu, (1) Observasi; Dokumentasi; (3) Wawancara; dan (4) Tes.

\section{Teknik Observasi}

Observasi adalah pengamatan meliputi kegiatan pemusatan perhatian terhadap suatu obyek dengan menggunakan alat indra, yaitu pengamatan secara langsung (Arikunto, 
2002:133). Observasi dalam penelitian ini dilakukan dengan cara observasi sistematis dengan pedoman yang telah disiapkan. Data yang ingin diperoleh dalam penelitian ini yaitu aktivitas siswa selama proses pembelajaran berlangsung yang meliputi perhatian terhadap pelajaran, belajar kelompok, pengerjaan tugas, diskusi dan bertanya, serta aktivitas siswa selama belajar kelompok yang meliputi, kualitas interaksi, keterlibatan siswa dalam kerja kelompok, presentasi hasil diskusi dan hasil kerja kelompok. Untuk mempermudah mendapatkan data, peneliti dibantu oleh seorang observer yang sudah mendapat kepercayaan dari peneliti dan guru pada saat pengambilan data. Pedoman yang akan digunakan pada saat observasi antara lain:

1. Pedoman observasi, yaitu berisikan tentang peraturan atau tata tertib dalam melaksanakan observasi.

2. Panduan pengamatan, yaitu berisikan tentang tata cara pemberian nilai, tercakup dalam kriteria atau kategori penilaian.

\section{Lembar pengamatan}

\section{Teknik Dokumentasi}

Teknik pengumpulan data dengan dokumentasi ialah pengambilan data yang diperoleh melalui dokumen-dokumen. Dengan teknik dokumentasi, kita dapat mengumpulkan data dengan melihat beberapa dokumen sebagai bahan informasi tambahan atau bukti autentik sebagai penunjang dalam pengumpulan data penelitian.

\section{Teknik Wawancara}

Menurut Arikunto (dalam Wahyuningsih, 2006:22), wawancara atau interview adalah sebuah dialog yang dilakukan oleh pewawancara untuk memperoleh informasi dari terwawancara. Pada penelitian ini digunakan wawancara bebas terpimpin, dimana pewawancara membawa pedoman pertanyaan yang hanya berupa garis besarnya saja dan pengembangannya dilakukan pada saat wawancara berlangsung. Wawancara dilakukan setelah pelaksanaan tes. Wawancara dilakukan dengan pedoman pada pekerjaan siswa yang berupa tugas pengajuan soal dan tes hasil belajar. Data yang diperoleh adalah data tanggapan guru dan siswa tentang proses dan hasil pembelajaran setelah diterapkannya pembelajaran kooperatif model $N H T$.

\section{Teknik Tes}

Teknik tes adalah salah satu cara pengumpulan data berupa angka atau nilai hasil belajar dengan cara penilaian dan evaluasi.

\section{Teknik Analisis Data}

Analisis data dalam penelitian ini adalah deskriptif kualitatif yaitu memaparkan data hasil pelaksanaan tindakan yang mencakup proses pembelajaran dengan model pembelajaran kooperatif tipe NHT dan nilai hasil belajar siswa. Selanjutnya dilakukan refleksi untuk mengkaji apa yang telah berhasil dan apa yang belum berhasil dituntaskan dalam pelaksanaan tindakan.

Analisis data yang digunakan dalam penelitian ini antara lain:

\section{Observasi}

Untuk mengetahui persentase aktivitas siswa selama proses pembelajaran berlangsung yang meliputi, perhatian terhadap pelajaran, belajar kelompok, pengerjaan tugas, diskusi dan bertanya, serta aktivitas siswa selama belajar kelompok yang meliputi kualitas interaksi, keterlibatan anak dalam kerja kelompok, presentasi hasil diskusi dan hasil kerja kelompok, digunakan rumus sebagai berikut.

$$
P a=\frac{M}{N} x 100 \%
$$

\section{Keterangan:}

$\mathrm{Pa}=$ Persentase aktivitas siswa selama proses penerapan model pembelajaran kooperatif tipe $N H T$.

$\mathrm{M}=$ Jumlah siswa yang mendapat kategori tinggi / sangat tinggi.

$\mathrm{N}=$ Jumlah seluruh siswa 


\section{Wawancara}

Data yang diperoleh dari hasil wawancara tersebut di analisis secara deskriptif. Adapun langkah-langkah yang ditempuh antara lain:

1) Mengumpulkan hasil wawancara

2) Membuat kelompok - kelompok hasil wawancara yang terdiri dari:

a. Pendapat siswa tentang pembelajaran IPS Ekonomi dengan menggunakan model pembelajaran kooperatif tipe NHT.

b. Pendapat guru tentang pembelajaran IPS Ekonomi dengan menggunakan model pembelajaran kooperatif tipe NHT.

c. Kendala-kendala / kesulitan yang dihadapi siswa pada saat mengerjakan tes.

d. Hasil belajar siswa

3) Mengumpulkan hasil wawancara berdasarkan kelompok yang telah ditentukan.

4) Mendeskripsikan masing-masing kelompok hasil wawancara.

\section{Tes}

Hasil belajar siswa diperoleh dari hasil ulangan harian yang dilakukan di akhir setiap siklus. Dari hasil belajar ini, dapat diketahui ketuntasan hasil belajar yaitu:

a. Ketuntasan perorangan, seorang siswa dikatakan telah tuntas dalam belajar jika ia mencapai > 70 dari skor maksimal 100.

b. Ketuntasan klasikal, siswa dikatakan tuntas secara klasikal bila dikelas tersebut terdapat minimal $85 \%$ siswa yang tuntas.

Untuk menghitung ketuntasan hasil belajar siswa digunakan rumus:

$$
P=\frac{n}{N} x 100 \%
$$

\section{Keterangan}

$\mathrm{P}=$ Tingkat ketuntasan hasil belajar.

$\mathrm{N}=$ Jumlah siswa yang tuntas belajarnya.

$\mathrm{N}=$ Jumlah semua siswa.

Berdasarkan rumus persentase di atas, hasilnya dijadikan bahan diskusi balikan dan sebagai tindak lanjut pada siklus berikutnya. Tindakan selanjutnya adalah peneliti melakukan refleksi berdasarkan hasil observasi dan hasil belajar siswa selama pelaksanaan tindakan.

\section{HASIL DAN PEMBAHASAN}

Penerapan model pembelajaran Numbered Head Together (NHT) pada mata pelajaran IPS dengan kompetensi dasar mendeskripsikan hubungan antara kelangkaan sumber daya dengan kebutuhan manusia yang tidak terbatas siswa kelas VIII-C di SMP Negeri I Arjasa berhasil mencapai ketuntasan klasikal. Hal ini dapat dilihat dari hasil observasi aktivitas belajar dan nilai ulangan harian.

Hasil observasi aktivitas belajar siswa sebelum tindakan pada indikator mengajukan pertanyaan $65,48 \%$, berdikusi $71,43 \%$,dan memecahkan soal $76.19 \%$ dari jumlah siswa yang aktif. Sedangkan hasil ketuntasan belajar klasikal sebelum tindakan $71,43 \%$, hasil belajar tersebut tidak mencapai kriteria ketuntasan klasikal yang dijadikan pedoman oleh peneliti.

Hasil pengamatan observer pembelajaran pada siklus I diperoleh data aktivitas belajar siswa dengan rincian yaitu, $73,81 \%$ siswa yang aktif dalam mengajukan pertanyaan, $75,00 \%$ siswa yang aktif berpikir bersama dan $78,57 \%$ siswa yang aktif memecahkan soal. Pembelajaran pada pertemuan I siklus I, skor keaktifan siswa 75,79 \% dengan kategori aktivitas Cukup Aktif. Sedangkan pada pertemuan II siklus I data aktivitas belajar siswa pada indikator mengajukan pertanyaan $79,76 \%$ siswa yang aktif, berpikir bersama $77,38 \%$ dan memecahkan soal $78,57 \%$ dari siswa yang aktif. Skor rata-rata yang diperoleh 78,57\% dengan kategori aktivitas Cukup Aktif. 
Setelah pembelajaran siklus I dan observasi aktivitas belajar siswa, dilaksanakan tes ulangan harian untuk membandingkan hasil belajar sebelum tindakan dan setelah tindakan penerapan model pembelajaran Numbered Head Together (NHT). Ketuntasan belajar siswa meningkat $7,14 \%$ setelah dilakukan pembelajaran pada siklus I meskipun hasil tersebut belum mencapai nilai kriteria ketuntasan klasikal siklus. Ketidaktuntasan pembelajaran siklus I, peneliti melanjutkan penerapan model pembelajaran Numbered Head Together di siklus II.

Berdasarkan hasil wawancara yang dilakukan pada beberapa siswa yang tidak tuntas mengatakan bahwa ketidaktuntasan siswa karma tidak siap menghadapi materi yang diajarkan. Hal ini dikarenakan siswa tidak belajar sebelumnya, ada sebagian siswa yang tidak memperhatikan saat guru menjelaskan materi pelajaran dan dalam kegiatan berpikir bersama sebagian siswa yang hanya melihat temannya tanpa memberi pendapat pada kelompoknya.

Perencanaan yang dilakukan peneliti pada siklus II ini sama dengan sebelumnya yaitu mempersiapkan instrumen pembelajaran, rencana pelaksanaan pembelajaran dengan model Numbered Head Together (NHT), mempersiapkan lembar oberservasi aktivitas belajar siswa dan aktivitas guru, format ulangan harian siswa serta pedoman wawancara siswa. Pelaksanaan pembelajaran siklus II, siswa tampak terbiasa dengan penerapan pembelajaran Numbered Head Together (NHT) dan lebih siap dalam menerima materi pembelajaran. Hal ini tampak pada aktivitas siswa dalam mengikuti proses belajar yang berlangsung. Pada siklus II pertemuan I observer melakukan observasi terhadap aktivitas belajar siswa dengan hasil sebanyak 19 siswa atau 83,33\% yang aktif mengajukan pertanyaan, 13 siswa atau $76,19 \%$ yang aktif berpikir bersama dan 16 siswa atau $83,33 \%$ yang aktif memecahkan soal. Skor aktivitas belajar siswa yang diperoleh pertemuan I adalah $80,95 \%$ dengan kategori aktivitas Baik.
Pada siklus II pertemuan II, hasil observasi aktivitas belajar siswa pada indikator mengajukan pertanyaan ada 16 siswa atau 77,38 \% aktif, berpikir bersama 21 siswa atau $89.29 \%$ aktif dan memecahkan soal sebanyak 23 siswa atau 91,67\% aktif. Sedangkan skor aktivitas belajar siswa yang diperoleh pada pertemuan II sebesar 84,31\% dan dalam kategori aktivitas Baik. Setelah pelaksanaan pembelajaran siklus II berakhir, peneliti mengadakan tes ulangan harian siswa untuk mengukur peningkatan hasil belajar antara siklus I dan siklus II. Adapun hasil belajar yang diperoleh pada pelaksanaan siklus II yaitu 24 siswa yang tuntas secara individu dan mencapai nilai persentase ketuntasan klasikal sebesar $85,7 \%$ dan jika dibandingkan dengan hasil belajar yang diraih siswa pada siklus I, terjadi peningkatan sebesar $3,57 \%$, dari data hasil belajar tersebut dapat dibuktikan bahwa penerapan pembelajaran Numbered Head Together (NHT) dapat meningkatkan aktivitas dan hasil belajar siswa.

\section{KESIMPULAN}

Berdasarkan hasil penelitian dan pembahasan, penelitian ini dapat disimpulkan bahwa:

1. Dari hasil pelaksanaan pembelajaran dengan menggunakan pembelajaran kooperatif Numbered Head Together (NHT) diketahui ada peningkatan aktivitas siswa dari siklus I hingga akhir siklus II. Pada pembelajaran siklus I pertemuan I aktivitas siswa yang diperoleh adalah $75,79 \%$ sedangkan siklus I pertemuan 2 sebesar $78,57 \%$ dengan kategori aktivitas cukup aktif. Pelaksanaan siklus 2 dengan perolehan persentase mencapai aktifitas siklus I pertemuan $180,95 \%$ hingga pertemuan 2 mencapai $86,11 \%$.

2. Pembelajaran dengan menerapkan model kooperatif tipe Numbered Head Together (NHT) mampu meningkatkan hasil belajar siswa dari hasil ulangan prasiklus sebesar $71,43 \%$ meningkat $7,14 \%$ pada siklus I dengan perolehan persentase ketuntasan siswa $78,57 \%$. Sedangkan 
pada siklus II mencapai persentase ketuntasan sebesar $85,71 \%$. Hal ini membuktikan bahwa model pembelajaran kooperatif tipe NHT mampu meningkatkan hasil belajar siswa.

\section{DAFTAR PUSTAKA}

Arikunto, S. 2000. Dasar-dasar Evaluasi Pendidikan. Jakarta: Bumi Aksara.

Arikunto, S. 2002. Prosedur Penelitian, Suatu Pendekatan Praktik. Jakarta: Rineka Cipta.

Cooper, et, Al. 1999. Classroom Teaching Skill, Edisi 9. Virginia: Univ of Virginia.

Dimyati dan Mudjiono. 2002. Belajar dan Pembelajaran. Jakarta: Rineka Cipta.

Djamarah. S.B. \& Aswan Zaini. 1999. Strategi Belajar Mengajar. Jakarta: Rineka Cipta.

Djamarah, S.B. 2002. Strategi Belajar Mengajar. Jakarta: Rineka Cipta.

Hakim. 2001. Belajar Secara Efektif. Jakarta: Puspa Swara.

Ibrahim, M. dkk. 2004. Pembelajaran Kontekstual (Contextual Teaching and Learning/ CTL) dan Penerapan dalam KBK. Malang: Univ. Negeri Malang.

Lei, A. 2005. Mempraktekkan Cooperative Learning di Ruang-ruang Kelas. Jakarta: Grasindo.

Nur. 2001. Pembelajaran Kooperatif. Surabaya.

Nurhadi dan Senduk. 2003. Pembelajaran Kontekstual dan Penerapannya dalam $K B K$. Malang: Universitas Negeri Malang.

Sudjana. 2002. Belajar dan Pembelajaran. Bandung. Alfabeta

Sugiyono. 2005. Memahami Penelitian Kualitatif. Bandung: Alfabeta.

Sukidin, Basrowi \& Suranto. 2002. Manajemen Penelitian Tindakan Kelas. Jakarta: Insan Cendekia.

Surakhmad, W. 2003. Pengantar Interaksi Belajar Mengajar Dasar dan Tehnik Metodelogi Pengajaran. Bandung; Tarsito.

Tim Pelatihan Proyek PGSM. 1995. Penelitian Tindakan Kelas. Jakarta: Dirjen Pendidikan Tinggi.

Winataputra. 2001. Model-model Pembelajaran Inovatif. Jakarta: Universitas Terbuka. 